\title{
En sorts bildningsroman
}

\section{ANDERS STEPHANSON}

Vietnam fanns med naturligtvis, men man måste börja med Novaja Zemlja. Det var på dessa avlägsna öar i Arktis, nordost om Skandinavien, som Sovjetunionen i oktober I96I testade den dittills (och hittills) största kärnladdningen: en väldig atmosfärisk explosion på hundra megaton (får vi veta). I verkligheten tycks den ha varit på 50 plus megaton, men även på den storleksnivån var den mer än femton hundra gånger så stor som Hiroshimabomben. Jag följde nedfallskartan med största intresse. Jag var elva år och mer än oroad i det annars skäligen lugna Kristinehamn i Värmland. Jag hade tagit till mig min fars allvarliga förutsägelse att min generation skulle uppleva något långt mer ödeläggande än hans, ja, faktiskt, världens slut i en kärnvapenkatastrof. Ett år senare blev den skrämmande realismen i den förutsägelsen existentiellt tydlig i Kubakrisen, det utan överdrift farligaste enskilda ögonblicket i världshistorien. Till min outsägliga lättnad löstes krisen. Den följdes faktiskt av en viss stabilisering i de så viktiga relationerna mellan USA och Sovjetunionen. Tack vare heta linjer och det partiella provstoppsavtalet 1963 avtog rädslan

Den här artikeln som reflekterar över utvecklingen av den egna forskningen publicerades ursprungligen på engelska som "A Bildungsroman of sorts" i det akademiska nätverket H-Diplos essäserie "Learning the Scholar's Craft: Reflections of Historians and International Relations Scholars", essä nr 264, 4 augusti 2020 (https://issforum.org/essays/ PDF/E264.pdf). Till denna svenska översättning har vi också fogat Stephansons avslutande (opublicerade) kommentar till den debatt han fört med Johan Lagerkvist i Dagens Nyheter i april 202I. 
för kärnvapenutplåning gradvis. Och det gjorde följaktligen också min övertygelse att jag inte skulle uppnå vuxen ålder. Den kinesiska "avvikelsen" - anskaffningen av bomben 1964 och de allt våldsammare angreppen på Sovjets position - tjänade bara till att understryka att det fanns en ny normalitet i förhållandet som verkligen hade betydelse. Då var det i stället den vidgade kampen för medborgerliga rättigheter i USA och de skrämmande bilderna av brinnande buddistiska munkar i Saigon som trädde i förgrunden. Något nytt var på gång.

Även om "Vietnam” fortfarande framställdes som ett huvudsakligen amerikanskt problem i behov av en bättre lösning växte känslan när jag såg dessa bilder i Life Magazine (som vi av någon anledning prenumererade på) att detta inte tillhörde det traditionella kallakrigsspelet. För mycket snart fick Vietnam, oavsett vilken ståndpunkt man intog, karaktären av ett djupt vietnamesiskt fenomen: sydvietnamesiskt, nordvietnamesiskt, revolutionärt, antiimperialistiskt, nationalistiskt, vad det nu än var, men otvivelaktigt vietnamesiskt. Ändå förutspådde jag i en fingerad tidningsartikel skriven i grundskolan långa och hårda "förhandlingar" enligt den styrande premissen att detta i sista hand var en amerikansk operation och fråga. Det amerikanska fokuset förstärktes senare starkt när jag flyttade till en liten stad i norra Michigan i Mellanvästern där jag tillbringade ett år som utbytesstudent. Det var till överväldigande del en republikansk plats, "anständigt republikansk" skyndar jag mig att tilllägga eftersom George Romney (Mitts far) var en tämligen liberal guvernör. Staden var vidare liljevit. Detroit, Motown, bilstaden och central rikedomskälla trettio mil söderut, var i det avseendet mycket avlägsen, något man insåg till fullo under den följande sommaren då metropolen stod i lågor i en av I960-talets dödligaste "rasoroligheter". "Raskampen" och medborgarrättskampen hade varit intensivt närvarande i mitt "amerikanska” intresse, men egendomligt nog var min faktiska erfarenhet på plats nästan lika avlägsen som den svenska. "Småstadsmichigan” var som kulturellt och socialt system vänligt men samtidigt ytterst repressivt, med ett normativt styre som var så mycket mer effektivt som det framstod som "frivilligt". Till syvende och sist var det den konstanta själv-inspektionen som bestämde graden av anpassningen till de sociala konventionerna om lämpligt beteende. Alexis de Tocqueville och Michel 
Foucault, som jag då inte hade läst, skulle ha känt igen förfarandet. Det var därför ingen överraskning för mig att det följande "sextiotalet", trots medborgarrätts- och antikrigskamp, skulle få den liberala och till och med libertarianska inriktning i USA som det fick (sammanfattat i uppmaningen "gör din egen grej").

Jag deltog under det året (1966-67) ständigt i diskussioner om Vietnam och kom småningom till slutsatsen att det bara fanns en enda rimlig lösning: tillbakadragande. Ingen höll med. Det var kanske inte så konstigt. Det som då var konstigt (och fortfarande är det) var ointresset av att få mer information. Trots allt stod de som gick ut från min high school inför inkallelse till militärtjänstgöring, några skulle tjänstgöra och några skulle dö. Mina åsikter väckte dock ingen uppståndelse; de förklarades uppenbarligen av mitt utländska ursprung och kom i skuggan av min plats i skollaget i tennis. "Erfarenheten" gav mycken lärdom men om vi av heuristiska skäl nedlåter oss till att skriva historia bakåt inom en teleologisk ram hade en sådan relevant aspekt tvunget med "Vietnams" vietnamesiska karaktär att göra: hela projektet fick allt mindre mening inom "kalla kriget", en term som i sig var på väg att förkastas. Vietnam var inte kallt, det handlade inte om en monolitisk kommunism som erövrade den fria världen, och försvaret av den sydvietnamesiska regimen var inte ett försvar av demokratin (under en period ledd av en gestalt som var djupt imponerad av Hitlers disciplinära dygder). Sedan dess har talet om något uppenbart "kallt krig" för mig alltid varit ett villospår som fördunklar de väsentligen amerikanska källorna till periodiseringsbegreppet och leder till alla möjliga historiska och ideologiska återvändsgränder. Detta var alltid en minoritetsståndpunkt. Sedan 199i har den faktiskt framstått som egendomlig.

Min viktigaste "lärdom" från ett år av diskussioner i Michigan hade dock inte så mycket med internationella relationer att göra som med övertygelsen om att skillnad någonstans måste vara en historisk skillnad och därmed kräva mera allmänna studier i amerikansk historia. I likhet med många européer hade jag slagits av det snäva spannet av politiska ståndpunkter (till exempel konsensusen om kalla kriget), bakom vilket låg en viss frånvaro, frånvaron av ett större politiskt parti på vänsterkanten med bas i arbetarrörelsen. Min modell och norm var naturligtvis 
Europa, en föreställning som jag borde ha ifrågasatt mer. På universitetet fortsatte jag sedan att följa den vältrampade europeiska stigen på jakt efter en förklaring till varför arbetarrörelsen misslyckades i USA: historien om fackföreningsbildning, statens och kapitalets otyglade förenade makt, den ideologiska karaktären hos de två (relativt) stora ögonblicken och misslyckandena för vänsterkristallisering, nämligen Socialistpartiet under den "progressiva eran" i början av 1900-talet och Kommunistpartiet under depressionsårtiondets senare del.

Dessa undersökningar sysselsatte mig under grundstudierna och de första forskaråren i Sverige och Storbritannien. När jag av en slump (som så ofta sker) hamnade på doktorsprogrammet vid Columbia University hade jag också kommit så långt det gick att komma i fråga om arbetarrörelsens historia. Systematiska ifrågasättanden var nästan politiskt omöjliga för arbetarrörelsen efter kriget, och förvisso efter 1948, så jag omorienterade mig gradvis bakåt mot internationella relationer och "kalla kriget". Det senare hade trots allt politiskt tjänat till att avsluta diskussionen om arbetarrörelsens politiska misslyckande. Det bör noteras att New York i varje avseende var antitesen till Småstadsmichigan: här riktades inga som helst anspråk på identitet och sätt att vara. Detta var också befriande i förhållande till de förutsägbara förväntningar som rådde i Småstadssverige, även om mängder av turister därifrån kunde dyka upp i staden och bli starkt förtjusta medan för motsvarigheterna i Michigan förblev New York (antar jag) en djupt främmande plats.

I slutet av 1970-talet och början av 1980-talet präglades Columbia och dess historieinstitution av ett visst missmod, oförmögna som de var att komma vidare efter omvälvningarna 1968-69. Vad institutionen beträffar hade omvälvningen sammanfallit med den eminente Richard Hofstadters förtidiga död. Institutionen (mycket större än motsvarigheten på svenska universitet) framstod som en åldrande och modfälld forskarmiljö trots framstående medlemmar. Men förändring stod för dörren. Staden reste sig med besked, Columbia College blev det elitställe man skulle gå på, och Eric Foner, Hofstadters student, återvände till institutionen och vitaliserade amerikansk I80o-talshistoria och mer därtill. Institutionen vidgade gradvis hela forskningsfältet även om Foner (liksom jag själv) alltid bevarade ett starkt engagemang för "politisk historia". 
Två kvarstående aspekter av mina studier i arbetarhistoria urskiljs i det nuvarande sammanhanget: framväxten av "teori" och exponeringen för "Williamsskolan". "Teori" (som ofta reifierades) antog till en början för mig "althusserianismens" form. Louis Althussers distinktion mellan vetenskap och ideologi och det direkta angreppet på den officiella marxismen, som tycktes ha förfallit till ideologiska plattityder och enkel partipropaganda, öppnade för svåra (och ibland överdrivna) epistemologiska problem och komplexa "strukturalistiska" framställningar av staten

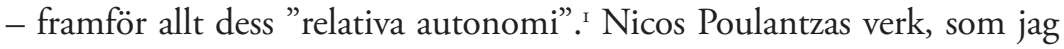
läste i skarven mellan gymnasium och universitet, var här av stor vikt. ${ }^{2}$ Allt som allt frambringade detta "moment" en "regional" analys av specifika apparater, och sedan Althusser väl hade utvecklat sin redogörelse för hur ideologi faktiskt opererar skapades förutsättningar för mer intressanta och övertygande representationer av det verkliga. Livskraften hos det slaget av teori avtog i senare delen av 1970-talet och ersattes av olika former av poststrukturalism (också främst av franskt ursprung), varav jag fann en hel del vara mindre användbart utom i "tekniska” termer - olika sätt att läsa texter. Två "lärdomar" har stannat kvar hos mig ända sedan dess. För det första den tvingande nödvändigheten av teori i en eller annan form gentemot å ena sidan empiristiska metodologier (inte att förblanda med "det empiriska beläggets protokoll”) och å andra sidan reduktionism, det vill säga elimineringen av "nivåers" och "regioners" relativa autonomi. För det andra fanns övertygelsen att det primära i tolkningen av motsägelserna i samhällsformationen som sådan låg på det politiskas nivå. Eller annorlunda uttryckt: man kom inte ifrån den betydelse som staten hade som förtätning, eller åtminstone primär artikulering, av det politiska.

I. De centrala referenserna är Louis Althusser, För Marx (Staffanstorp: Cavefors, I968) och Louis Althusser \& Étienne Balibar, Att läsa Kapitalet. I-2 (Staffanstorp: Cavefors, 1970). Båda kom ursprungligen ut i Frankrike 1965. Althussers reviderade ideologibegrepp presenterades i essän "Ideologi och ideologiska statsapparater" från 1970. På svenska i Filosofi från proletär klasståndpunkt (Staffanstorp: Cavefors, 1976).

2. Nicos Poulantzas, Politisk makt och sociala klasser (Mölndal: Partisan, 1970). Poulantzas Fascism och diktatur (Stockholm: Coeckelberghs, 1973), som fortfarande är oöverträffad, var viktig för min förståelse av det sovjetiska fascismbegreppet och särskilt av den följande antifascistiska strategin som småningom återanvändes i den berömda tvålägersmatrisen från 1947 och framåt. 
Allteftersom "teori" mer och mer gick över till textuella, litterära och småningom kulturella intressen bevarade jag därför en lojalitet mot vad som klumpigt brukade kallas "statens specificitet", hur mycket den positionen än på ett produktivt sätt komplicerades av både den teoretiska och den empiriska utvecklingen, framför allt inom forskning om "ras" och kön.

Trots min disciplinära skepsis mot den "kulturella vändningen" (med faran att en diffus "kultur" skulle komma att ersätta politik och teori) råkade jag i den så kallade verkliga världen i början och mitten av 1980talet engagera mig i New Yorks florerande konstvärld och den samtidigt pågående debatten om postmodernism, framför allt den begreppsbildning och periodisering som utgick från Fredric Jameson (som i den mån man här vill åberopa namn och den uråldriga "influensaspekten" har förblivit en vän och samtalspartner jämte Perry Anderson). Jag hade alltid varit intresserad av konst, och politisk konst i synnerhet, ett intresse som intensifierades sedan jag som gymnasist sett en fantastisk utställning i Stockholm av sovjetisk konstruktivism och 1920-talets avantgarde innan stalinismen blev allenarådande. Den postmoderna fixeringen vid ytan och bilden, den arkitektoniska förvandlingen av rummet, simulakrumets framväxt och attackerna mot alla "djupmodeller" - Jameson presenterade om man så vill en djupdiagnos av djuplösheten - bildade en både intellektuell och starkt kommersiell värld av största intresse. ${ }^{3}$ Detta förde med sig ett starkare engagemang för historiskt tänkande ("historisera alltid!", som Jamesons stridssignal löd) mitt i nuets och ytans postmoderna intensitet. Det förde också med sig ett sätt att läsa George Kennans kritik av den amerikanska kapitalismens masskultur, hans djupt konservativa misstro mot individualistisk atomisering. ${ }^{4}$ President Ronald Reagan

3. Den omedelbara referensen här (det finns många fler) är Fredric Jameson, ”Postmodernismen eller senkapitalismens kulturella logik", i Mikael Löfgren \& Anders Molander (red.), Postmoderna tider? (Stockholm: Norstedts, 1986). Generellt var det viktigaste verket för mig annars Jamesons Det politiska omedvetna. Berättelsen som social symbolhandling (Stockholm: Symposion, 1994). Vad gäller Perry Anderson måste jag särskilt hänvisa till Övergångar från antiken till feodalismen (Lund: Arkiv förlag, 2004), Den absoluta statens utveckling (Lund: Arkiv/Zenit, 1994) och Om den västerländska marxismen (Lund: Arkiv förlag, 1984).

4. Kennans kritik av masskulturen i USA (och väst i allmänhet) finns överallt, men ett representativt smakprov kan man finna i Melvin J. Laskys intressanta "A Conversation with Kennan", Encounter, 78 (mars 1960), s. 46-57. 
kunde samtidigt uppfattas som postmodern pastisch ("ytan" förkroppsligad) vid sidan om hans korta men kraftfulla försök att starta ett andra kallt krig.

Den specifika miljön för en hel del av dessa intressen var mitt redaktionsarbete under 1980-talet för och i Social Text. Efter ett par livfulla år som medlem av Radical History Review anslöt jag mig till det nyligen grundade Social Text-kollektivet och kom att ägna en omåttlig massa tid åt det (läs: "gjorde inte min avhandling klar"). Tidskriften var interdisciplinär, eller snarare icke-disciplinär, och samtidigt som den erkände "kulturens" vikt utgick den explicit från att texten inte bara var en text, utan oåterkalleligt "social” med åtföljande krav på en adekvat redogörelse för den sfären. Erfarenheten visade sig vara högst stimulerande, ett slags parallell doktorandutbildning som spillde över i mina första år av undervisning (först på det utomordentliga Rutgers University med Warren Kimball och Lloyd Gardner och sedan tillbaka på Columbia). En speciell form, eller "subgenre", som jag utvecklade var den "seriösa intervjun" - försök till längre, inträngande meningsutbyten med individer jag råkade finna intressanta, från vänner som Fredric Jameson och Cornel West ${ }^{5}$ till Alec Nove (ekonomhistoriker med inriktning på Sovjetunionen), Dario Fo och Franca Rame (litteratur och teater), Barbara Kruger och David Hockney (konstnärer) och Boris Kagarlitskij (sovjetisk dissident). Dessa "verk", ibland i samarbete med andra, krävde ofta mycket förberedelser och redigering, en investering vars värde till slut inte var så självklar. Småningom slutade jag med det (det ligger vill jag minnas kvar ett opublicerat, tämligen uppriktigt samtal med Richard Rorty i någon låda). Till slut lämnade jag också i början av 1990-talet Social Text (året före den ökända Sokalaffären) - jag hade förlorat en intern konflikt om organisation och inriktning, en typ av konflikt som den sortens tidskrifter ofta råkar, eller råkade, ut för.

Tre konkreta konsekvenser följde för min historiska praktik efter "teori" - utöver obenägenheten (förlåt att jag blir kort här) att betrakta denna praktik som ett "hantverk" som man lär sig i ett lärlingskap, även om man ska komma ihåg att den store historiker som kallade detta för

5. Se intervjuerna med Fredric Jameson och Cornel West i Zenit, 95-96 (I-2, I987). 
"hantverk" också utvecklade begreppet feodalism. ${ }^{6}$ Den första konsekvensen hade att göra med forskningens objekt, eller "problematik", formandet av en viss samling frågor till en begreppsram av explicita och implicita termer. Min tendens var (och är) att utveckla en andra ordningens analys av en given politiskt laddad analys till en historia om begrepp, produktiva begrepp (här blev verk av Reinhart Koselleck och den tyska Begriffsgeschichteskolan högst betydelsefulla). ${ }^{7}$ Vilka är, kort sagt, de begreppsliga möjlighetsbetingelserna för att ett policyobjekt ska förstås som sådant? Den andra konsekvensen hade att göra med det metodologiska problemet att läsa och systematisera källor. Om en text saknar en bestämd innebörd (vi måste som bekant "producera" den för att kunna bedöma den på vederbörligt sätt) kan den inte utan vidare reduceras och fogas till en samling på liknande sätt reducerade källor och förvandlas till en redogörelse för vad som faktiskt hände. Men historia som intellektuellt produktionssätt bygger just på ett stort antal dokument som grävs fram, sammanfattas och ordnas till en berättelse om "vad som hände". Historiker har i allmänhet inte lyxen att kunna sitta och reflektera över en enda text eller två (låt oss säga trettiosex sidor av Ludwig Wittgenstein). Jag har själv alltid upplevt detta som ett predikament och en hämning. För det tredje och slutligen ledde min analytiska strävan mig ofta vilse såtillvida att jag tenderade att på de givna aktörerna lägga systematiska intressen som snart visade sig inte existera eller bara existera i en mycket rudimentär form.

Två exempel på detta sista drag kommer att räcka. New Deal som period, politiskt projekt och systematisk effekt är notoriskt svårt att fast-

6. Marc Bloch, The Historian's Craft (New York: Vintage Press, 1953) förblir utomordentligt användbar (franskt original Apologie pour l'histoire ou métier d'historien). Hans klassiska Feudal Society (La société féodale) publicerades i två band på Routledge \& Kegan Paul i London 196r. Bloch, medgrundare av franska Annalesskolan med dess interdisciplinära förhållningssätt till historia, var helt medveten om att historikerns hantverk inte kunde reduceras till ett hantverk i den enkla meningen av utveckling från lärling till mästare. Men givet frånvaron av varje tänkbar teorikanon tenderar disciplinen ändå att renodla sin kärna till en fråga om metod, företrädesvis källkritik.

7. Kosellecks (kollektiva) projekt förkroppsligas i det stora referensverket om "grundbegrepp": Geschichtliche Grundbegriffe (sju band, Stuttgart: E- Klett, 1972-92). För hans egen specifika version, se Reinhart Koselleck, Erfarenhet, tid och historia. Om historiska tiders semantik (Göteborg: Daidalos, 2004). 
slå, och i min undersökning av amerikanska kommunistpartiet (CPUSA) under 1930-talets depression var jag nyfiken på hur partiet på en teoretisk nivå hanterade denna svårighet. Det gjorde de inte. Först var New Deal "socialfascism" i vardande; sedan efter ett tämligen kort intervall blev det dominerande element $\mathrm{i}$ en förutsatt amerikansk version av folkfronten. Inte under någon av dessa båda perioder övervägde partiet (fann jag till min besvikelse och leda) på allvar konsekvenserna för hur man skulle förstå den kapitalistiska staten. Det fanns inte alls så värst mycket som motsvarade de krävande normerna i althusseriansk teori eller någon annan teori heller för den delen. Det som i stället torgfördes var ren ideologi. Denna min "upptäckt" var varken empiriskt slående eller, vid närmare eftertanke, någon större överraskning. Jag anser fortfarande att det var en god övning i vetenskapligt tålamod att gå igenom varje partipublikation från den perioden. Till slut hade jag också vunnit en konkret känsla för logiken - och det var en logik - i den sovjetiska antifascismen, den matris från slutet av 1930-talet som skulle komma att styra Moskvas syn på kalla kriget och USA efter andra världskriget.

Det andra exemplet, som ligger närmare nutida intressen, har att göra med amerikanska utrikesdepartementet under den omedelbara efterkrigstiden. När arbetarhistoria blev ett "avslutat kapitel" för mig i och med I930-talet graviterade jag, som nämnts, tillbaka till mitt tidigare intresse för "brotten" i USA:s internationella relationer (som jag typiskt förstod i epistemologiska termer), vars avgörande ögonblick självklart tycktes vara kalla kriget och dess berömda "ursprung". Här fanns ett annat periodiseringsproblem, ett politiskt projekt att bestämma, frågor om kunskap och vad som räknades som kunskap (en problematik som nu färgades, men bara färgades, av ett visst postalthusserianskt element av Foucault) - en kombination av grundbegreppens historia och den "diplomatiska historiens" traditionella konstitutiva intressen med beslut, handlingar, icke-handlingar, intressen, policyer i en sfär av relativ geopolitisk avskildhet. Rent kallakrigstänkande och kallakrigshandlande tycktes skriva in världen på ett alltför enkelt sätt sett utifrån det kloka egenintressets perspektiv - detta "intresse" som alternativt var den sammansatta syn som utvecklades av den kritiske Kennan från 1948 och framåt. Jag hade läst det klassiska första bandet av Kennans Memoirs, där 
han utvecklade ett (enligt min mening) långt mer intelligent och realistiskt sätt att främja amerikanska intressen än den rigida binära logik som faktiskt kom att råda. ${ }^{8}$ Ett sätt att driva detta både historiskt och analytiskt skulle då vara att se hur "neutralitet" spelades ut mitt i den amerikanska "antingen/eller-polariteten", och mer exakt hur det fungerade i det svenska fallet. Men efter ett visst inledande arbete informerades jag vänligt av Geir Lundestad att han just hade avslutat en bok, en alldeles utmärkt bok som jag snart upptäckte, om just detta ämne om än i en vidare skandinavisk ram. ${ }^{9}$ (Varför, undrar man i förbigående, denna skara prominenta nordiska historiker inom fältet för amerikanska internationella relationer? Sedan har vi också den italienska anomalin. Italien har också producerat ett förvånansvärt antal historiker på samma fält.) Jag insåg faktiskt att Lundestad hade besparat mig en massa meningslöst arbete eftersom det begreppsliga och politiska problem som jag hade formulerat egentligen inte var särskilt relevant: trots det återkommande väsandet om neutral omoral föstes det binära bekvämt och pragmatiskt åt sidan när det verkligen gällde. Dessutom var det ofta svårt att följa beslutsvägarna i amerikanska utrikesdepartementet (till skillnad från exempelvis dem i det brittiska utrikesdepartementet), och det fanns överraskande lite av sammanhängande reflektion över de vidare och djupare konsekvenserna av kalla krigets polaritet.

Utrikesdepartementet och Kommunistpartiet visade sig alltså båda lida brist - så att säga - på egentligt begreppstänkande. Kennan hade på sätt och vis lett mig vilse. Han befann sig på en unik nivå av analytisk stränghet om än utifrån en konservativ teorifientlighet. Eftersom han också under en kort men avgörande period intog en ledande position blev lösningen för mig på det stadiet självklar: glöm det Hela till förmån för det Enskilda, där det senare var Kennan själv. Detta visade sig vara kongenialt och livgivande. Han (och hans texter) har varit väsentliga för mig ända sedan dess.

8. George F. Kennan, Memoirs, I925-I950 (Boston: Little, Brown, 1980). Det förblir ett av de stora självbiografiska verken.

9. Geir Lundestad, America, Scandinavia, and the Cold War, 1945-1959 (New York: Columbia University Press, 1980). 
Efter två studier sålunda, ${ }^{10}$ präglade av teoretiska överdrifter å min sida, blev teori mer en fråga om hur man till att börja med ska tänka sig ett givet historiskt problem, ja, under vilka villkor det faktiskt kan bli ett problem av denna specifika ordning. Men forskningsobjekten förblev "grundbegreppen" inom politikens sfär, begrepp som bildar fält av besläktade termer och alltså genererar gränser, inre/yttre distinktioner, potential för handling av ena eller andra slaget. ${ }^{\text {II }}$ Mitt intresse för Kennan präglades av det sättet att tänka: med logiker (eller antinomier) som i hans fall ofta ledde till intressanta återvändsgränder eller åtminstone till platser på vilka han inte nödvändigtvis ville befinna sig. Ett väsentligt intresse från och med det ögonblicket blir alltså "kalla kriget”, dess förgreningar, dess gränser, dess periodisering, dess politik, dess själva status som begrepp. Mer specifikt var det "kalla kriget" använt som ett "kampbegrepp". Urtexten mitt ibland alla kontroverser om "revisionism" visade sig bli Walter Lippmanns omvälvande kritik av Kennan på hösten 1947, men innan jag säger ett ord om detta måste jag först spåra ursprunget längre bakåt $\mathrm{i}$ min egen formation till William Appleman Williams. Jag hade upptäckt Williams och hans krets under mina första universitetsår, då jag studerade arbetarhistoria och sökte få grepp om statens formering i slutet av I80o-talet och början av I900-talet. Då var det begreppet "företagsliberalism" (corporate liberalism) i en progressivistisk kontext som krävde uppmärksamhet - James Weinstein och Gabriel Kolko mer omedelbart än Williams. Givet althusserianismens våldsamma angrepp på ekonomism och reduktionism var detta för min del ett laddat angreppssätt (som jag till min egen höga tillfredsställelse kunde visa i min första universitetsuppsats var Charles Beard ekonomisk determinist medan Karl Marx inte var det). Ändå måste man erkänna

IO. Anders Stephanson, Kennan and the Art of Foreign Policy (Cambridge: Harvard University Press, 1989) och dessförinnan "The CPUSA Conception of the Rooseveltian State, 1933-1939" i Radical History Review, 24 (1980), s. I6I-I76.

II. Om "autonomin" och dess problem hade jag tidigt inspirerats av den tjocka sociologiuppsatsen i Lund av Maja Björkman, Daniel Fleming, Anders Kjellberg, Lennart Spång \& Bengt Åberg - ett teoreticistiskt "försök" som antagligen fortfarande är unikt - Klasskamp och klassamarbetspolitik i USA. En studie av den amerikanska arbetar-och borgarklassens organiseringssträvan och statens ingripanden i klasskampen frän I870-till I950-talet (Lund 1972). Hundra sidor inledande teori. 
att statens "relativa autonomi" i USA verkade vara nästan obefintlig, och att till och med den följande reformismen var mer begränsad än vad det verkade. Såtillvida var kritiken av liberalismen riktig även om den överdrev "reformens" list. Den övergång till "företagskapitalism" som skedde i Williams periodisering innebar som bekant framväxten av den "öppna dörren" (the open door), en aggressiv marknadssyn på utrikesintresset (den mest inträngande redogörelsen för detta i dess inhemska sammanhang fann man - till slut - i verk av hans uppfinningsrike student Martin Sklar). ${ }^{12}$ Williams själv var egendomligt nog egentligen idealist, filosofiskt såväl som politiskt, som i sista instans omfattade ett starkt utopiskt drag och ironiskt nog slutade sina dagar i en position - kommunitaristisk regionalism i brist på bättre ord - alldeles i närheten av Kennans. De framstående historiker som följde honom (Lloyd Gardner, Walter LaFeber och Thomas McCormick) stod i det avseendet närmare andra Wisconsinhistoriker, såsom Fred Harvey Harrington. Djup och bestående respekt för Williams var i vilket fall som helst hos mig förbundet med kritik av hans nyckelbegrepp Weltanschauung (som han med typiskt väderkorn hade plockat upp - en teoretisk impuls om man så vill - från Karl Mannheim och Georg Lukács, bortom dem från Wilhelm Dilthey och ännu längre bakåt G.W.F. Hegel och "objektiv idealism”): varje aspekt av den sociala totaliteten är uttryck för en inre princip (låt oss säga den ”öppna dörren”) så att det ideologiska uppnår en innebo-

I2. Vid sidan om hans berömda verk The Tragedy of American Diplomacy (Cleveland: World Publ., 1959) är Williams mest konsekvent genomförda studie - inte minst vad gäller den "öppna dörren" som periodiseringsverktyg - The Contours of American History (Cleveland: World Publ., I96I). Norton gav ut den på nytt 1988 och Verso $201 \mathrm{I}$ (med en introduktion av Greg Grandin). Se även Lloyd Gardner (red.), Redefining the Past. Essays in Diplomatic History in Honor of William Appleman Williams (Corvallis: Oregon State University Press, I986); och Paul Buhle \& Edward Rice-Maximin, William Appleman Williams. The Tragedy of Empire (New York: Routledge, 1995). Martin Sklar myntade under sin doktorandtid termen "företagsliberalism", och hans viktiga The Corporate Reconstruction of American Capitalism, I890-I9I6. The Market, the Law and Politics (Cambridge: Cambridge University Press, 1988) är direkt kopplad till Williams verk, och tvärtom kan man tillägga eftersom Williams tidigt lärde sig mer än en sak av Sklar. Men på 1990-talet var Sklar på vippen att röra sig mot högern (som han uppfattade som den faktiska vänstern), en omsvängning som skulle placera honom i ett högst egendomligt politiskt rum. 
ende materiell status och det vanliga problemet med "vikten och verkan av vad som sägs" kan elimineras med ett enda drag. Men till slut var det den politiska kritiken av kalla kriget som jag tog med mig från Williams. Och jag tyckte alltid att han hade rätt att (någonstans) kalla Kennan för den förste revisionisten.

Den våldsamma, intensivt politiska "debatt" om revisionismen som hade utspelat sig i professionen inom det större inhemska sammanbrottet i fråga om Vietnam och dess efterdyningar hade avtagit i slutet av 1980-talet men ersattes inte av något självklart annat fokus eller ramverk. Fragmenteringen inom disciplinen (och en påtaglig förlust av energi i själva deldisciplinen) ägde rum mot bakgrund av de snabba, världshistoriska förändringarna av geopolitiken: den iranska revolutionen, Ronald Reagan/Margaret Thatcher, Michail Gorbatjov, Tysklands enande, upplösningen av Sovjetunionen, Kuwaitkriget - kort sagt utraderingen av efterkrigstidens grundstruktur. Dessa avgörande händelser väckte en känsla av "slutet" eftersom det onekligen var slutet på den ordning som byggde på relationen mellan USA och Sovjetunionen. Och följaktligen blev det bekvämt och naturligt att beteckna det slutet som slutet på "kalla kriget". Jag höll inte med. För mig var det historiskt fel kom ihåg 1963 - och i vilket fall som helst suspekt eftersom det de facto accepterade Reagans ideologiska kritik av den föregående avspänningen på 1970-talet, tesen att kalla kriget aldrig slutade, varom vittnade Sovjetunionens världserövrande intentioner och expansionism. Det fullständigt självklara slutet definierades av Sovjetunionens slut; det var bara ett kort steg till att föreställa sig även "periodens" början som ett resultat av själva existensen av denna makt.

Jag överdriver lite. Den förhärskande uppfattningen var här inte fullffädrad reaganism utan en version av "ömsesidighetstesen”, det vill säga den vardagsförnuftiga iakttagelsen att kalla kriget var en period av extrem spänning mellan "de båda supermakterna" som upphörde när det bara var en kvar. Det rådde faktiskt inte längre något större intresse för ursprungets orsaker, och slutet självt låg fortfarande bortom våra arkivmässiga restriktioner. I stället fyllde subdisciplinen i tomrummen i vad som nu var en öppen karta av möjliga ämnen som kunde vara en funktion av, eller stå i samband med, en generaliserad världshistorisk period 
kallad "kalla kriget", som var global och begreppsligt obegränsad. I detta ögonblick av radikal förändring gick jag tillbaka till tidigare polemiker om struktur och ursprung. Jag började också tänka på ett mer konsekvent sätt kring den specifika karaktären hos kalla kriget som periodiseringsverktyg, vad för slags berättelser och analyser som det uppmuntrade till och vad det uteslöt.

Den avgörande utgångspunkten var här återigen Lippmanns kritik av "X-artikeln", som med dubbel ironi presenterade för allmänheten "kalla kriget" som term i en inträngande diagnos utan att egentligen diskutera det namn han just hade gett den. ${ }^{13}$ Jag ska inte upprepa detaljerna men referensen måste nämnas eftersom Lippmanns intervention hela tiden har tjänat som en klargörande källa. Lippmanns realistiska kritik kretsade kring Kennans oförenlighetstes: den underliggande föreställningen att Moskva och Washington på något sätt inte kunde ha med varandra att göra eftersom de drevs av olika begreppsscheman och, mer grundläggande, för att Sovjetunionen inte tillät egentliga avtal, karakteriserat som det var av fanatisk, oförsonlig expansionism. Tvärtom kan Sovjetunionen, säger Lippmann, se samma maktformationer som vi, och frågan om förhandlingar är reell och angelägen och ligger högst sannolikt i vårt intresse. Lippmanns kritik härleder sig $i$ sista instans från ett visst begreppsligt misstag som han upptäckte hos Kennan (och USA). Det bör noteras att den avgörande aspekten är upptäckten av ett policymisstag och inte, som man kunde tänka sig, en diagnos av "ömsesidigheten” som sådan, karakteriseringen av till exempel en symmetrisk situation, ett tillstånd, ett dödläge. Men även en sådan "ömsesidighet” var otillåten i den version av Kennans framställning som uppträdde som officiell amerikansk policy: "kalla kriget" blir ett inneboende drag hos Sovjetunionen självt, ja, faktiskt (den totalitära) upplösningen av själva distinktionen mellan krig och fred, där bara den överlägsna, preventiva kraften hos

13. Walter Lippmann, The Cold War. A Study in U.S. Foreign Policy (New York: Harper, 1947). De här samlade artiklarna kom ut på hösten 1947 under den allmänna rubriken "Kalla kriget”, men termen förklarades ingenstans. Målet var naturligtvis "X-artikeln", Kennans berömda artikel publicerad under pseudonymen X i julinumret av Foreign Affairs 1947. "The Sources of Soviet Conduct", som titeln egentligen lydde, inkluderade nästan ingen reflektion över effekten av det nyligen avslutade, monumentala kriget på östfronten. 
USA på en global nivå kunde hålla kriget kallt till skillnad från varmt eller hett. Vilket skulle bevisas. Efter 1947 anpassade Kennan de facto sig till Lippmanns realistiska argument. Detta steg förde faktiskt med sig en mer radikal brytning med kallakrigstänkandet än vad det atlanticistiska oraklet Lippmann själv någonsin skulle kunna uppbåda - eller ville uppbåda. (Kennans fortsatta villighet att då - I948 - använda fula metoder "under" den officiella konfliktens nivå ska inte dölja hans grundläggande villighet att "förhandla" med Moskva.)

Kalla krigets asymmetriska logik var dock mycket produktiv. Som Paul Nitze, den ledande kraften bakom NSC-68, erans mest oförblommerade policydokument (1950), insåg fanns det inga inneboende gränser för vad man kunde vilja göra; och kapaciteten fanns utan vidare till hands. Den rigida axiomatiken öppnade för flexibelt handlande i global skala, för vilken det primära målet egentligen var att skapa ordning i den "icke-totalitära” världen. Handlandet skulle naturligtvis läggas i den exekutiva maktens händer för att komma ifrån problemen med politiskt styre i ett decentrerat system av klass och stat.

Det tycktes mig i vilket fall som helst viktigt att dra fram det amerikanska ursprunget till detta ramverk och identifiera dess politiska förgreningar, även om det också fanns ett element av olust i de policyskapande kretsarna i fråga om själva termen (som Peter Slezkines kommande studie av det åtföljande begreppet "fria världen" kommer att visa). ${ }^{14}$ (Den farliga) föreställningen om "ömsesidighet" svävade alltid i bakgrunden: "det krävs två för att dansa tango", krig involverar två sidor och, vem vet, identitet kan mycket väl gömma sig någonstans i processen. Detta drag var faktiskt embryonalt närvarande i de olika vetenskapliga och kvasivetenskapliga diskurser (från cybernetik till rational choice-teori) som skulle komma att kretsa kring "kärnvapenspelet", vilket som bekant kulminerade i "ömsesidig garanterad ödeläggelse" (mutual assured destruction, MAD - den explicita benämningen på ömsesidighet efter 1962). Jag tyckte alltså också att det var viktigt att framhäva att "kalla kriget" förlorade sin logik när ömsesidighet inte bara var ett underjordiskt inslag, utan en dominant (för att använda en gammal althusserianism). Om

I4. Peter Slezkines verk har den provisoriska titeln Free World. The Creation of a U.S. Global Order. 
man inte tittar på kylfaktorn utan på frånvaron av öppet krig tillåter det kalla kriget som projekt ett helt spektrum av möjliga "nivåer" och handlingar inom den konstitutiva, dominanta ramen, som alla kan ha sin egen tidsliga och rumsliga karaktär och dynamik. Precis som det inte finns någon "krigsförklaring" finns det ingen "fred", bara erkännande och ömsesidighet. Och ömsesidighet var just vad Kubakrisen demonstrerade med största existentiella klarhet. Erkännande blev alltså tidens lösen, förvisso inte erkännande av "vänskaplighet" utan av ett avgörande behov av att hantera de fientliga relationerna, överbestämda som de i sista hand var av kärnvapenbalansen. Den mest akuta antagonismen i geopolitiken visade sig under tiden råda mellan Kina och Sovjetunionen. Denna antagonism undergrävde i sig varje "systemiskt" argument, vilket också kvasialliansen mellan Washington och den fortfarande ytterst radikala maoistregimen i Beijing gjorde.

Jag framförde detta argument vid flera tillfällen ( ja, det gick så långt att jag upprepade mig och själv tråkades ut). Men ett sådant "försök" förtjänar några ord här. Sent på våren 1996 publicerade $H$-Diplo i två avsnitt min artikel "Fourteen Notes on the Very Idea of a Cold War". is Formatet på dessa "anteckningar" var lite ovanligt. Artikeln var (på den tiden) för lång för att publiceras i ett enda stycke och anteckningarna själva bestod av miniessäer om olika gestalter (till exempel Hegel, Clausewitz, Lippmann, Don Juan Manuel, Augustinus, Marx, Franklin D. Roosevelt, Hobbes, Koselleck, John le Carré och så vidare) som kunde tjäna som referenser för en reflektion över den konventionella polaritet mellan krig och fred inom vilken varje beskrivning av "kalla kriget" som periodiseringsgrepp måste börja. För det första, vad för slags fred postulerade det, om det nu alls postulerade något? Jag lånade, lite ironiskt, titeln från Donald Davidsons hyllade essä "On the Very Idea of a Conceptual Scheme", även om en "anteckning" om hans angrepp på begreppsrelativismen skulle ha både förstärkt och försvagat mitt argument. Den ursprungliga inspiratören till dessa "anteckningar" var John Lewis Gaddis. Han hade medverkat till skapandet av H-Diplo men tyckte liksom jag att den (i mitten 1990-talet) var lite av en besvikelse med fokus främst på trivialiteter och ofruktbar polemik. Han föreslog

I5. Den finns på https://issforum.org/essays/PDF/stephanson-I4notes.pdf. 
(om inte minnet sviker mig) att jag skulle skriva något substantiellt för nätverket, så jag lät "anteckningarna” rassla iväg tämligen snabbt. Det var kanske inte vad Gaddis hade haft i åtanke, men det skilde sig förvisso vad gällde spännvidd från den vanliga kosten. Reaktionen blev öronbedövande tystnad. Den udda formen och det udda innehållet spelade här en roll, men $H$-Diplo var då platsen för mycket åsiktsutbyte så bristen på reaktion överraskade mig ändå.

Periodiseringsmålet var naturligtvis redan förlorat - kanske ett mer grundläggande skäl till bristen på reaktion. Något världshistoriskt inträffade uppenbarligen 1989-9I, och det enklaste sättet att karakterisera detta var att hänvisa till "kalla kriget" och dess "slut". Med början och slutet uppenbarligen på plats blev termen en kliché och uppnådde så att säga en reifierad soliditet, samtidigt som den inom de osäkra men vida gränserna öppnade för studier av det ena med det andra (många av dem värdefulla). Senare har det gjorts vårdslösa hänvisningar till diverse "nya kalla krig" som om det vore ett transhistoriskt fenomen likställt med till exempel "krig". Det bästa man under tiden kan hoppas på är ett medgivande av att "kalla kriget" i strikt bemärkelse kan ses som en fas inom det större och längre kalla kriget. Vi kan nu tre decennier efter dess påstådda "slut" faktiskt vara på väg att stöpa om den avgörande upplösningen (och därmed "kalla kriget") till ett underordnat moment i hela den ungefär sjuttio år gamla "efterkrigsperiod" som kunde kallas den "liberala världsordningen", det vill säga den period av amerikansk hegemoni (terminologin kan diskuteras) då "ledarskap" hävdades med rätta och "nödvändighet" och det skedde framsteg utomlands trots beklagansvärda misstag som Vietnam; allt i skarpaste kontrast till det gyckelspel som nu (av Trump) visas upp i Vita huset. Det behövs inget större språng i fantasin för att i detta se en liberal omarbetning av den urgamla mytologin om manifest destiny, USA:s inneboende öde att expandera, en trevligare version av det globala suveränitetsbegrepp som Bush den yngre till min stora överraskning hade återupplivat några år efter att jag skrivit en mindre bok om ämnet. ${ }^{16}$ Jag hade trott att mytologin hade begravts under 1990-talet, ett tidevarv som ju styrdes av devisen "mer och bättre

16. Anders Stephanson, Manifest Destiny. American Expansionism and the Empire of Right (New York: Hill \& Wang, 1995). 
globalisering" under finansdepartementets och Wall Streets ledning. Jag borde ha vetat bättre.

Det skulle ligga nära till hands att beskriva denna utflykt i genren "USA i världen" - beteckningen som var på väg att ersätta det hopplöst föråldrade "diplomatins historia" - som ett välbetänkt och klarögt försök från min sida att gå med strömmen. I verkligheten var det ett beställningsjobb och dessutom ett överraskande sådant. Den koncisa formen som krävdes - empirisk redogörelse med analytisk omsorg - var hälsosam. Det "bestämda ödet", manifest destiny, som var en väsentlig del av det dunkla komplex som ofta samlades under den vilseledande paraplytermen "amerikansk exceptionalism", tillät reflektion över de religiösa (mer exakt protestantiska) aspekterna av hur man föreställde sig vissa avgörande ögonblick av expansion hos USA - "öde" som såväl bestämmelse och destination som tid och rum. Jag har sedan dess haft mer än en anledning att tänka igenom saken på nytt, och inte bara på grund av den oväntade "återuppståndelsen" av uttrycket. Det fanns till exempel distinktionen mellan uppdrag och messianism: USA var alltid i viss mening "missionerande" men som legendarisk förmedlare eller överbringare av goda nyheter drev det bara då och då saken till det messianskas sfär i rollen som faktisk (sekulär) frälsare. Men när det verkligen gällde kvarstod alltid den politiska kulturens axiom, den absoluta övertygelsen, att USA var den världshistoriska nationen par préférence. USA är Världen men Världen är inte USA, och i den klyftan ligger ett ansenligt utrymme för potentiell handling. 


\section{PS. Den liberala världsordningen. Avslutande kommentar till en debatt med Johan Lagerkvist i Dagens Nyheter}

Historiker är i periodiseringsbranschen. Vi delar upp homogen tid i kvalitativa enheter, kallar dem perioder och förklarar deras uppgång och fall, deras orsaker, karakteristika, effekter. Alla människor periodiserar - vi kan "inte inte periodisera" som Fredric Jameson har uttryckt det men historiker gör det systematiskt. Termerna kan vara mer eller mindre deskriptiva, mer eller mindre förklarande. Till de förra hör konsthistoriens stilbegrepp, till de senare, säg, "senkapitalismen". Periodiseringsbegrepp förklarar dock ingenting i sig. De kräver teorier och tillhörande begrepp som redogör för orsakssammanhang och varför kronologin ser ut som den gör.

Det var ur den synvinkeln jag hade invändningar mot Johan Lagerkvists tal om ett "nytt kallt krig" som förklarande beskrivning av Kinas relationer med omvärlden och framför allt den västliga. Termen har blivit journalistisk kliché snarare än historisk förklaring, en simpel idé om risiga stormaktsförhållanden med vag genklang i perioden när polariteten mellan Washington och Moskva dominerade geopolitiken. Som kliché fördunklar den både dåtid och nutid. Att "slutet på det kalla kriget" konventionellt identifieras med Sovjetunionens upplösning gör det vidare lätt att identifiera ursprunget med Sovjetunionen och dess karaktär, precis som den amerikanska uppfattningen på I950-talet ville göra gällande.

Vi kan lämna den debatten åt sitt öde. Notabelt nu är att det "kalla kriget" under senare år kommit att inrangeras under en ny periodisering av formidabel ideologisk karaktär, den "liberala världsordningen" (the liberal world/international order, eller LWO, för det är ett amerikanskt påfund och akronymer är de rigueur).

I7. Johan Lagerkvists ursprungsartikel "Välkommen till det nya kalla kriget med supermakten Kina" publicerades i Dagens Nyheter 28 mars 202I (https://www.dn.se/kultur/kulturdebatt-valkommen-till-det-nya-kalla-kriget-med-supermakten-kina/). Jag svarade den 5 april, ”Ett nytt kallt krig med Kina? Knappast, läget är annorlunda” (https://www.dn.se/ kultur/anders-stephanson-ett-nytt-kallt-krig-med-kina-knappast-laget-ar-annorlunda/), och Lagerkvist replikerade den 12 april, "Kina är inte en pendang till USA:s historia" (https://www.dn.se/kultur/johan-lagerkvist-kina-ar-inte-en-pendang-till-usas-historia/). 
En fördel med LWO som periodisering är att den beskriver hela tidsepoken sedan andra världskriget tills dags dato. Man behöver ingen term för tiden "efter det kalla kriget". Idén är enkel. Efter 1945 (eller 1947) skapades under USA:s ledning ett världsomspännande system utanför den sovjetiska sfären, ett system som var liberalt i sin anda, ekonomi och politik. Det fanns visserligen illiberala inslag inom LWO, men USA och liberalismen var överbestämmande. Ett hegemoniskt regelverk styrde. Sovjetunionens fall sedermera - rätt långt senare - innebar naturligtvis ett enormt framsteg ur det här perspektivet. Likaså Kinas införlivande i den kapitalistiska världsekonomin. Historiens slut? Nja, kanske inte. LWO är ett tillsvidareprojekt.

Dess diskursiva effekt är tvådelad. Å ena sidan öppnar den för en allomspännande, traditionell amerikansk roll i världen. Systemets grundförutsättning är just USA:s roll - the indispensable nation, den oumbärliga nationen. Å andra sidan förutsätter den ingen specifik fiende, ingen dualism bortom den generella fiendefunktionen. Hoten mot sagda ordning kan växla beroende på omständigheterna, terrorism, populister, auktoritära politiker av fientligt slag, Kina på alla möjliga sätt inklusive (kan det så sägas) ett nytt kallt krig. Donald Trump? Ingen liberal men mera prat än verkstad visade det sig. Den nya periodiseringen täcker fall av radikal dualism som det klassiska kalla kriget men är vidare och flexiblare. Dess favoriserade maktmedel, allrahelst efter diverse misslyckade miltära operationer, är sanktionen. Starkt ideologiserad har denna bild nu kommit i gungning genom Kinas agerande, på en nivå en förstålig reaktion mot den givna hegemonin, på en annan klumpig taktik. 

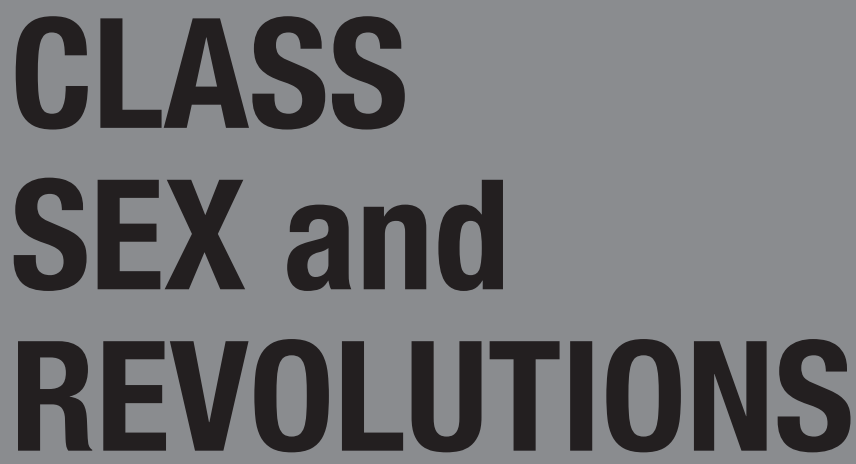

\section{Göran Therborn - a critical appraisal}

In between Science, Class and Society (1976) and The Killing Fields of Inequality (2013) Göran Therborn has consistently challenged received wisdom in politics and the social sciences. Today his work is spread across six continents, Latin America in particular, and has been translated into more than twenty languages.

This book is a critical appraisal of the themes Göran Therborn has pursued up till now, and is introduced by Robin Blackburn, for almost twenty years his editor at New Left Review. The book is edited by Gunnar Olofsson and Sven Hort.

Contributors include among others Perry Anderson, Chang Kyung-sup, Anita Göransson, Eric Hobsbawm, Habibul Haque Khondker, Åsa Cristina Laurell, Lena Lavinas, Bo Rothstein, Anders Stephanson, Immanuel Wallerstein, Karin Widerberg, Erik Olin Wright and Elisabeth Özdalga.

\section{ARKIV FÖRLAG, 436 pages}

\section{"Read more about the book at www.arkiv.nu»}




\section{Perry Anderson x 3}

\section{Övergångar från antiken till feodalismen}

(Arkiv förlag 2004, 312 sidor)

Övergångar från antiken till feodalismen har sedan sin publicering 1974 etablerats som det internationella standardarbetet om det förkapitalistiska Europas historia. Bokens centrala tema är Europas utveckling från antiken till medeltiden och de olika vägarna som Öst- och Västeuropa kom att ta.

\section{Den absoluta statens utveckling (Arkiv/Zenit 1994, 609 sidor)}

I Den absoluta statens utveckling fortsätter Perry Anderson sin storslagna framställning av de europeiska statsbildningarnas utveckling. I fokus står absolutismen och hur detta statssystem växte fram och kom att utvecklas i öst och väst.

\section{Om den västerländska marxismen}

(Arkiv förlag 1984, 290 sidor)

Om den västerländska marxismen är en storslagen exposé över den "västerländska" marxismens utveckling från 1918. Boken tar upp alla de viktiga traditionerna, från Lukács, Gramsci och Frankfurtskolan fram till Sartre och Althusser. Ett centralt tema i boken är också en diskussion om "marxismens kris" samt en uppgörelse med strukturalistiskt och poststrukturalistiskt tänkande. 